\title{
Rozwój mobilnych usług płatniczych w małych i średnich przedsiębiorstwach
}

\section{Development of Mobile Payment Services in Small and Medium Enterprises}

Streszczenie: Celem artykułu było określenie powodów wdrażania bezgotówkowych form płatności w przedsiębiorstwach małej i średniej skali, ze szczególnym uwzględnieniem płatności mobilnych. Podstawą badania były dane wtórne i pierwotne. Dane pozyskano z raportów Narodowego Banku Polskiego (NBP), Komisji Nadzoru Finansowego (KNF), Głównego Urzędu Statystycznego (GUS) i systemów kart płatniczych. Okresem badań były lata 2015-2019. Aby ocenić decyzje przedsiębiorstw MŚP dotyczące wprowadzenia mobilnych form płatności, przeprowadzono badania ankietowe, inspirując się modelem teorii akceptacji technologii. Jak wykazały analizy, coraz więcej przedsiębiorców zauważa wzrastający popyt na płatności mobilne, płynący z rynku i zmian otoczenia zewnętrznego. Największe znaczenie ma zgłaszane zainteresowanie klientów tą formą płatności. Zmiany wynikają też ze świadomości przedsiębiorców dotyczącej potrzeby zmiany strategii biznesowych. Przedsiębiorstwa, które wdrożyły mobilne systemy płatności, traktowały te działania jako zwiększenie swojej pozycji konkurencyjnej. Ranga tych czynników była wysoko notowana w hierarchii uzyskanych ocen. Większą otwartość w obszarze wdrożenia mobilnych płatności stwierdza się w przedsiębiorstwach średniej skali. Największe znaczenie w tym względzie miało dla nich zainteresowanie klientów tą formą płatności. Dla małych firm elementem stymulującym otwarcie na zmiany okazuje się częstotliwość rezygnacji klientów z zakupów. Lokalizacja działalności gospodarczej skorelowana z liczbą potencjalnych klientów pozytywnie stymuluje aktywne postawy przedsiębiorców względem nowoczesnych form płatności i wiąże się ze wzrostem akceptacji dla tych płatności.

\begin{abstract}
The aim of the study was to determine the reasons for implementing non-cash payment services in small and medium enterprises, with focus on mobile payments. The basis of the study were secondary and primary data. Data were obtained from the reports of the National Bank of Poland, Polish Financial Authority, Central Statistical Office, payment card systems. The research period covered the years 2015-2019. In order to examine SME enterprises decisions regarding the introduction of mobile payment methods carried out were surveys inspired by the technology acceptance theory model. As the analysis showed more entrepreneurs notice the growing market demand for mobile payments and changes in surrounding environment. Customers' interest in this form of payment were of great importance.
\end{abstract}


The changes are due to the awareness of entrepreneurs of the need to change business strategies. Enterprises that implemented mobile payments treated these activities as increasing their competitive position. The rank of these factors were high in the hierarchy of grades obtained. The greater activity in the implementation of mobile payments occurs in medium-sized enterprises. For small businesses the element stimulating openness to changes is the customers' withdrawing from making purchases. The location of business activity correlated with the number of potential customers positively stimulates the active approach of entrepreneurs to modern forms of payment and the increased acceptance of these payments.

Słowa kluczowe: płatności mobilne; przedsiębiorstwo MŚP; przyczyny; rozwój

Keywords: development; determinants; mobile payments; SME enterprises

Otrzymano: 3 listopada 2019

Received: 3 November 2019

Zaakceptowano: 15 kwietnia 2020

Accepted: 15 April 2020

\section{Sugerowana cytacja/Suggested citation:}

Filip, P. (2020). Rozwój mobilnych usług płatniczych w małych i średnich przedsiębiorstwach. Przedsiębiorczość - Edukacja [Entrepreneurship - Education], 16(1), 326-338. doi: 10.24917/ 20833296.161.26

\section{Wstęp}

Transakcja w obrocie gospodarczym to umowa dwustronna pomiędzy sprzedającym a kupującym, która ma na celu wymianę towaru lub usługi. Transakcja finansowa to pojedynczy akt lub operacja gospodarcza, w której następuje jednorazowy przepływ pieniądza. W bieżącej działalności operacyjnej przedsiębiorstwa ważnym jest zwiększanie korzyści finansowych z przeprowadzonych transakcji sprzedaży produktów, towarów czy usług. W wyniku operacji finansowych następuje zmiana posiadanych składników przedsiębiorstwa na realny pieniądz. Pieniądz uzyskany z transakcji wymiany w obrocie gospodarczym pozwala przedsiębiorstwom na kreację zysku netto, dalszą realokację zasobów, prowadzenie inwestycji i rozwój przedsiębiorstwa zgodnie z przyjętą strategią. Obok uzyskanych korzyści finansowych efektem zrealizowanej transakcji mogą być skutki gospodarcze, majątkowe, wizerunkowe i inne (Czarny, 2018). Transakcje finansowe odnoszą się w praktyce do zmian między różnymi kategoriami wierzytelności i długów, czyli należności oraz zobowiązań. Pozyskiwanie pieniądza z rozliczeń końcowych to dla przedsiębiorców niezwykle ważny element ich funkcjonowania i rozwoju. Ze względu na formę płatności w praktyce gospodarczej spotykamy transakcje gotówkowe i bezgotówkowe. Aby rozpoznać zakres istniejących płatności w polskim systemie, przeprowadzono badanie raportów, sprawozdań z rynku finansowego i dokumentów monitujących rynek płatności. Ideą badań było zwrócenie uwagi na zakres korzystania z bezgotówkowych systemów płatniczych i możliwości stosowania nowoczesnych form płatności. Zgodnie z ustawą o działalności gospodarczej, dokonywanie lub przyjmowanie płatności związanych z wykonywaną działalnością gospodarczą następuje głównie za pośrednictwem rachunku płatniczego przedsiębiorcy (Ustawa $z$ dnia 6 marca 2018 r. Prawo przedsiębiorców). Podmiotem badań były przedsiębiorstwa małej i średniej wielkości (MŚP), gdyż ta grupa przedsiębiorstw jest ważnym sektorem polskiej gospodarki (Filip, 2017; 
Hossain, 2015). Przeprowadzono wieloetapowe badania własne, prowadząc analizy przez pryzmat zachowań klientów i przedsiębiorstw. Zbadano stopień korzystania polskich konsumentów z poszczególnych form płatności w latach 2015-2018, bowiem to konsumenci w transakcjach sprzedaży decydują, jaką formę płatności zastosują - gotówkową czy bezgotówkową. W tym celu przeanalizowano poziom i strukturę zrealizowanych płatności, ze szczególnym uwzględnieniem transakcji bezgotówkowych, w tym także płatności bezgotówkowych bez użycia karty. Przeprowadzono również badania dotyczące istniejących zasobów infrastruktury technicznej, zakresu korzystania z usług bankowości internetowej oraz internetu w przedsiębiorstwach MŚP, które mogą stanowić potencjał rozwojowy dla wdrażania nowoczesnych form płatności. Badanie właściwe stanowiły badania ankietowe przeprowadzone w 2019 r. na terenie województwa podkarpackiego w celowo dobranych przedsiębiorstwach. Celem badania było przedstawienie oceny zmian zachodzących na rynku mobilnych płatności bezgotówkowych z perspektywy przedsiębiorców jako akceptantów oraz rozpoznanie możliwości dla rozwoju mobilnych usług płatniczych w przedsiębiorstwach ze względu na wielość przedsiębiorstwa i lokalizację działalności gospodarczej. W badaniach wykorzystano model teorii akceptacji technologii poszerzony o czynniki, które mogą przewidzieć stopień zmian w przedsiębiorstwach względem nowych, innowacyjnych form płatności. Płatności mobilne to przeprowadzanie transakcji płatniczych z wykorzystaniem urządzeń przenośnych, takich jak telefony komórkowe czy komputery kieszonkowe. Ta nowoczesna forma płatności nabiera ostatnio znaczenia w kontekście pojawiających się zmian globalnych i rozwoju technologii informatycznych, a także powszechności istniejących zasobów internetowych. Jej pojawienie na rynku polskim jest datowane na okres prowadzenia badań.

\section{Sposoby płatności w Polsce na tle istniejących zasobów infrastruktury}

Dane o formach i zakresie płatności bezgotówkowych oraz istniejącej infrastrukturze technicznej służącej tego typu płatnościom pozyskano z raportów Narodowego Banku Polskiego (NBP), Komisji Nadzoru Finansowego (KNF), Głównego Urzędu Statystycznego (GUS), systemów znanych kart płatniczych (Master Card, Visa) i portali internetowych stale monitorujących rozwój rynku kart płatniczych i płatności zbliżeniowych. W pierwszym etapie badań przeanalizowano poziom i dynamikę transakcji gotówkowych i bezgotówkowych zrealizowanych Polsce dla obranego okresu badań (tabela 1).

Biorąc pod uwagę strukturę płatności w ostatnich latach, zauważamy wyraźną zmianę form płatności stosowaną przez polskich klientów w transakcjach kupna-sprzedaży produktów, towarów i usług. W strukturze płatności widoczna jest zmiana proporcji struktury zapłaty na rzecz korzystania z płatności bezgotówkowych. Udział płatności gotówkowych w transakcjach ogółem w okresie poprzedzającym badanie ankietowe spadł o 5,7\% i obecnie wynosi zaledwie 11,9\% ogółu transakcji. Natomiast płatności bezgotówkowe przeanalizowane w czasie wykazały dużą dynamikę wzrostu z 77,3\% udziału do 88,1\%, przy wzrostach płatności ogółem związanych ze wzrostem wolumenu sprzedaży. Tempo zmiany zrealizowanych transakcji bezgotówkowych było duże. W kolejnych okresach odnotowano w tej grupie wzrosty o ponad 25\%, 21\% i 30\%, relatywizowane rok do roku. Są one zdecydowanie wyższe niż transakcji ogółem. Przeprowadzona wstępna obserwacja rynku krajowego potwierdza, że polscy konsumenci preferują płatności bezgotówkowe, co potwierdzają też liczne badania (Chmielarz, 2005; IPSOS, 2017; Kozakiewicz, Kwas, 2014). 
Ważna dla klientów staje się oszczędność czasu i użyteczność tego typu transakcji. Transakcje bezgotówkowe mogą być przeprowadzane w różnych formach, m.in. z użyciem kart płatniczych, a także bez użycia kart płatniczych za pomocą aplikacji internetowych (Eftekhari, Bogers, 2015; Pacak, 2014). Udział transakcji bezgotówkowych bez użycia karty w odniesieniu do transakcji bezgotówkowych ogółem nie jest duży. Oscyluje na poziomie od 2,3\% do 3,4\%, ale co charakterystyczne - systematycznie wzrasta. W ujęciu liczbowym był to ponad dwukrotny wzrost względem pierwszego okresu przyjętego do analizy. Średnie roczne tempo wzrostu transakcji bezgotówkowych bez użycia karty wynosi blisko 50\%, za wyjątkiem roku ostatniego (5,6\%), co świadczy o dynamicznym rozwoju tej formy płatności i jej popularności wśród klientów. Pojęcie mobilności pochodzi od łacińskiego słowa mobile, które oznacza 'ruch, zdolność do poruszania, przemieszczania się' (Borcuch, 2007). System mobilny koncentruje swą uwagę na produkowaniu i dystrybucji produktów, które wykorzystuje się w obiegu, ruchu (Kim, Park, Yeon, 2016; Maciejewski, Polasik, 2009), a to podnosi jego walory użytkowe. Zakres tych płatności reguluje ustawa o elektronicznych instrumentach płatniczych i usługach płatniczych (Ustawa $z$ dnia 12 września 2002 r....).

Aby zdiagnozować możliwości zastosowania płatności bez użycia karty, zbadano potencjał infrastruktury technicznej do realizacji transakcji bezgotówkowych. Oceniono istniejący stan liczby urządzeń i placówek z terminalami POS (ang. point of sale - punkt handlowy), umożliwiających kontakt $\mathrm{z}$ bankiem za pośrednictwem centrum autoryzacyjnego oraz tych, które są odpowiednio przystosowane do płatności mobilnych, a także ogólną liczbę placówek, w których akceptuje się płatności dotykowe oraz placówek, które akceptują płatności mobilne. Z przeprowadzonych analiz wynika, że systematycznie wzrasta liczba urządzeń infrastrukturalnych umożliwiających płatności mobilne, co kreuje dostępność i możliwość świadczenia tego rodzaju usług (tabela 2).

Urządzenia dla płatności mobilnych stanowią ponad $72 \%$ ogółu zarejestrowanych urządzeń. Ich udział w 2018 r. wzrósł do 89,3\%, co oznacza, że istniejące zasoby infrastruktury technicznej umożliwiają świadczenie tego typu płatności. Wskaźnik dynamiki obliczony dla kolejnych lat wskazuje na systematyczne, równomierne i dynamiczne inwestycje w ten typ urządzeń. Urządzenia dla płatności mobilnych używane są do kontaktu z bankiem za pośrednictwem centrum autoryzacyjnego przez liczne spółki uwierzytelniające płatności kartami w celu rozliczenia transakcji handlowych. Zakres inwestycji rzeczowych w tego typu urządzenia jest wyższy niż w pozostałe oprzyrządowanie. Świadczy to o wzrastających inwestycjach infrastrukturalnych w urządzenia przeznaczone do płatności mobilnych i nastawieniu się sprzedawców na obsługę w tych systemach. Z kolei liczba punktów akceptujących płatności mobilne względem zainstalowanych urządzeń charakteryzuje się mniejszym udziałem i mniejszym wskaźnikiem dynamiki. Liczba urządzeń przypadających na placówki akceptujące płatności mobilne wyniosła w badanym okresie 1,51 do 1,56 urządzenia na jednostkę i wykazywała podobne zależności o charakterze względnej stałości. W 2018 r. wskaźnik ten wzrósł do poziomu 1,86. Z badania tych relacji wnioskować należy, że zasoby infrastrukturalne do płatności mobilnych w ujęciu ilościowym uległy zwiększeniu, a liczba przedsiębiorstw oferujących płatności mobilne do zasobów była nadal niższa. Około jedna trzecia placówek miała niewykorzystany potencjał do płatności bez użycia karty i mogła się otworzyć na mobilne formy płatności. Podkreślić należy, że istniejąca infrastruktura i urządzenia do przyjmowania płatności bezgotówkowych mogły być podstawą poszerzenia oferty usług płatniczych i otwarcia się 
$\Xi$

ज़

है

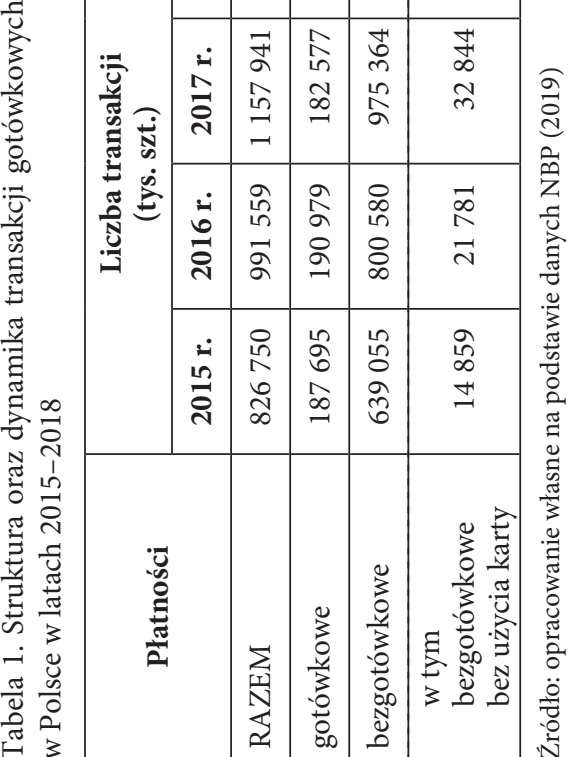

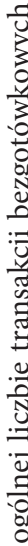

ํำ

ปับ

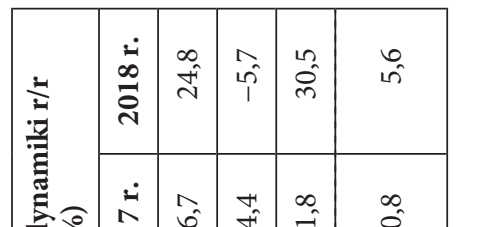

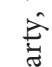

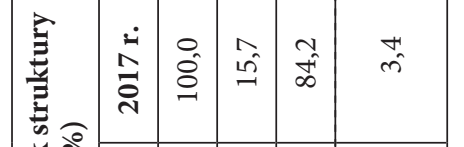

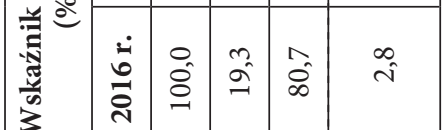

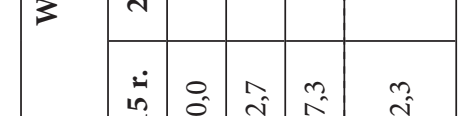

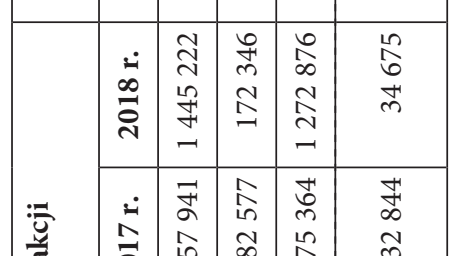

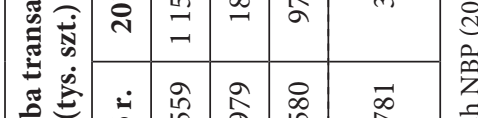

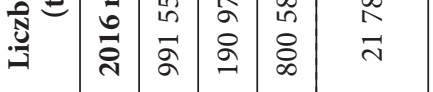

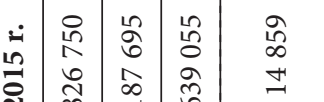


kolejnych przedsiębiorstw na nowe, innowacyjne systemy płatności. Na takie zmiany powinien być otwarty badany sektor przedsiębiorstw małej i średniej skali.

Dostęp do internetu w małych i średnich przedsiębiorstwach oraz sposoby wykorzystania internetu

Dostęp do zasobów internetowych jest dla przedsiębiorstw tym czynnikiem, który może być szerzej wykorzystanym. Internet staje się stałym zasobem infrastruktury niematerialnej obecnym aktualnie w wielu przedsiębiorstwach, a zakres jego wykorzystania może być wielokierunkowy. Przedsiębiorstwa MŚP wykorzystują internet głównie dla swoich wewnętrznych potrzeb. W przedsiębiorstwach małych i średnich wykorzystanie internetu $\mathrm{w}$ zakresie transakcji rozliczeniowych jest dwukierunkowe, jako odbiorca i jako dawca płatności finansowych możliwych do zrealizowania za pomocą sieci internetowej (tabela 3).

Tabela 3. Charakterystyki dokonywanych płatności przez przedsiębiorstwa MŚP korzystające $\mathrm{z}$ usług bankowości internetowej i mobilnego internetu.

\begin{tabular}{|c|c|c|c|c|c|c|c|}
\hline \multirow[b]{2}{*}{ Przedsiębiorstwa MŚP } & \multicolumn{4}{|c|}{ Lata } & \multicolumn{3}{|c|}{ Zmiana (\%) } \\
\hline & 2015 & 2016 & 2017 & 2018 & $\begin{array}{l}2016 / \\
2015\end{array}$ & $\begin{array}{l}2017 / \\
2016\end{array}$ & $\begin{array}{l}2018 / \\
2017\end{array}$ \\
\hline $\begin{array}{l}\text { Srrednia wartość przelewu } \\
\text { / } 1 \text { przedsiębiorstwo }\end{array}$ & 4354,94 & 3654,24 & 3955,82 & 4240,08 & $-16,1$ & 8,2 & 7,1 \\
\hline $\begin{array}{l}\text { Średnia liczba rozliczeń } \\
\text { /1 klienta }\end{array}$ & 19 & 20 & 18 & 19 & 5,0 & $-10,0$ & 5,5 \\
\hline $\begin{array}{l}\text { Średnia wartość rozliczeń } \\
\text { /1 przedsiębiorstwo }\end{array}$ & 69028,72 & 72094,16 & 73137,04 & 74446,3 & 4,4 & 1,5 & 1,8 \\
\hline $\begin{array}{l}\text { Liczba przedsiębiorstw } \\
\text { z dostępem do } \\
\text { bankowości internetowej }\end{array}$ & 2347224 & 2356156 & 2362249 & 2486659 & 0,3 & 0,2 & 5,2 \\
\hline $\begin{array}{l}\text { Liczba aktywnych } \\
\text { przedsiębiorstw }\end{array}$ & 1350228 & 1403767 & 1445999 & 1586807 & 3,9 & 3,1 & 9,7 \\
\hline Odsetek aktywnych (\%) & 57,52 & 59,57 & 61,21 & 63,81 & 1,0 & 2,7 & 4,2 \\
\hline $\begin{array}{l}\text { Mobilny dostęp do } \\
\text { internetu (\%): } \\
\text { - małe przedsiębiorstwa } \\
\text { - średnie przedsiębiorstwa }\end{array}$ & $\begin{array}{l}57,30 \\
78,40\end{array}$ & $\begin{array}{l}60,40 \\
80,40\end{array}$ & $\begin{array}{l}65,80 \\
84,20\end{array}$ & $\begin{array}{l}63,70 \\
82,20\end{array}$ & $\begin{array}{l}5,4 \\
2,5\end{array}$ & $\begin{array}{l}8,9 \\
4,7\end{array}$ & $\begin{array}{l}-3,1 \\
-2,3\end{array}$ \\
\hline
\end{tabular}

Źródło: NET@bank, Związek Banków Polskich (2019), GUS (2019)

Liczba przedsiębiorstw MŚP z dostępem do usług bankowości internetowych jako głównego kanału płatności bezgotówkowych jest w miarę stała. Wzrasta aktywność przedsiębiorstw w wykorzystaniu kanału bankowości internetowej do dokonywania i przyjmowania płatności bezgotówkowych. Aktywność ta mierzona może być takimi wskaźnikami, jak: średnia wartość przelewu, średnia liczba rozliczeń, przeciętna kwota rozliczeń, dostęp do bankowości internetowej. Odsetek aktywnych przedsiębiorstw małej i średniej skali korzystających z usług internetowych oscyluje w granicy 60\% użytkowników. W 2018 r. odnotowano nieznaczny wzrost do poziomu 63,8\%. Kontrahenci 
przedsiębiorstw dokonują przeciętnie 20 płatności miesięcznie. Liczba płatności rozliczeniowych obecnie nieznacznie spadła, wzrosła natomiast średnia wartość jednego przelewu. Średnia wartość przelewu dokonana przez przedsiębiorstwo MŚP wzrosła o około 7-8\% w ujęciu nominalnym, przy miarę stałej średniej wartości rozliczeń odniesionej do pojedynczego przedsiębiorstwa. W ostatnich latach wielkości wybranych wskaźników płatności bezgotówkowych wyrównały swoje notowania. Świadczyć to może o stabilizacji rynku płatności bezgotówkowych w dotychczasowej postaci lub względnym jego nasyceniu. Chociaż rozwój rynku płatności bezgotówkowych w grupie małych i średnich przedsiębiorstw jest zadowalający, to potencjał rozwoju wydaje się być jeszcze duży. Elementem zmiany może być zwiększony zakres korzystania z mobilnego internetu.

Zakres korzystania z internetu jest stosunkowo wysoki, a jak wynika z powyższych danych, wzrasta też nasycenie przedsiębiorstw MŚP bezprzewodowym internetem mobilnym. Urządzenia mobilne do dokonania płatności pozwalają na łączność z siecią telekomunikacyjną (GSM czy internetem). Jak wykazują analizy, zasoby internetowe w polskich przedsiębiorstwach systematycznie wzrastają i mają dobry stopień nasycenia (GUS, 2019). W przedsiębiorstwach małej i średniej skali zwiększa się udział mobilnego internetu. Zmianę stopnia nasycenia należy na tle ogółu użytkowników ocenić pozytywnie pod względem skali zmian. Mobilny dostęp do Internetu jest zdecydowanie wyższy w grupie średnich przedsiębiorstw. Różnica w dostępie do mobilnego internetu oscyluje w granicach rozstępu 20\%, z korzyścią na rzecz pozytywnych zmian w średnich przedsiębiorstwach. Współpraca telekomunikacji komórkowej z internetem tworzy swoisty rodzaj rozszerzenia przestrzeni wirtualnej i podstawy do rozwoju skali realizowanych płatności mobilnych (Ghobakhloo, Arias-Aranda, Benitez-Amado, 2011). Najczęstszym

Rycina 1. Mobilny dostęp do internetu w małych i średnich przedsiębiorstwach w latach 2015-2018

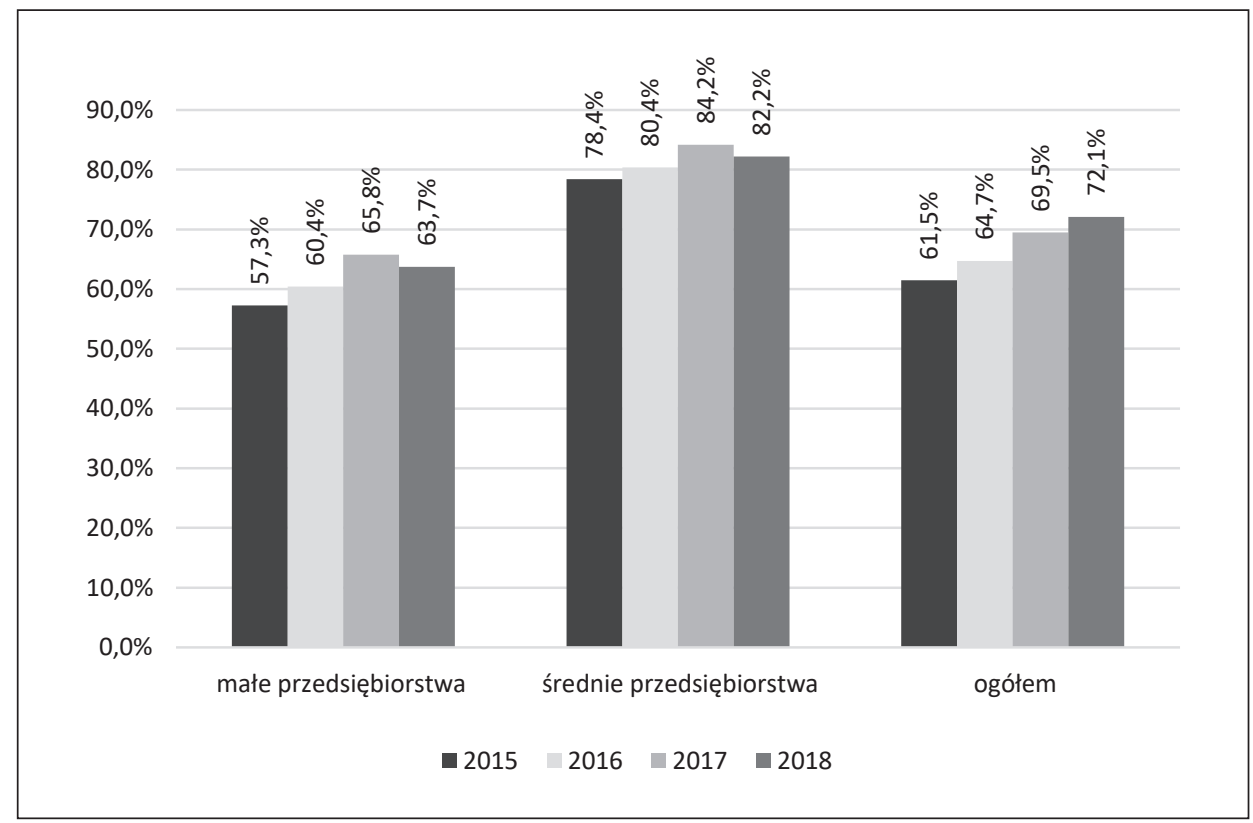

Źródło: opracowanie własne na podstawie danych GUS (2019) 
rozwiązaniem stosowanym do obsługi płatności bezgotówkowych jest terminal stacjonarny dzierżawiony od agenta rozliczeniowego, a następnie terminal przenośny.

Podsumowując, pierwszy etap badań wskazuje, że istniejące zasoby infrastrukturalne i ich rodzaj stwarzają dużą niezależność przedsiębiorstw dla wdrożenia nowoczesnych form płatności i usprawnienia procesu sprzedaży. Obecność sieci bezprzewodowych w obecnym stanie w połączeniu z siecią internetu umożliwia wdrażanie oprzyrządowania i systemów dla mobilnych urządzeń elektronicznych.

\section{Powody wprowadzania mobilnych usług płatniczych w przedsiębiorstwach}

Aby sprawdzić postawy i decyzje przedsiębiorstw MŚP dotyczące wprowadzenia mobilnych form płatności, zastosowano badania ankietowe, które przeprowadzano na terenie województwa podkarpackiego. Dobór przedsiębiorstw badań był celowy, zachowano w nim strukturę odzwierciedlająca charakterystyki sektora przedsiębiorstw MŚP, uwzględniając jego wielkość, rodzaj i miejsce prowadzonej działalności. Przy opracowaniu formularza ankiety wykorzystano model teorii akceptacji technologii, który pozwolił wyjaśnić zaangażowanie przedsiębiorstw w korzystanie z nowych technologii. Jego uniwersalny charakter i popularność powodują, że jest on stosowany w objaśnianiu użytkowania różnego rodzaju technologii informacyjnych w różnych kontekstach społecznych (Davis, 1989). Zachowanie przedsiębiorstw związane z wykorzystaniem technologii informacyjnych i wdrażaniem nowinek technologicznych determinowane może być przez wiele czynników, m.in. przez intencję użycia, percepcję, przydatność postrzeganą przez użytkownika, postawę przedsiębiorstw wobec użycia danego rozwiązania technologicznego (Szmigielska, Wolski, Jaszczak, 2012). W założeniach badawczych to właśnie rozpoznanie postaw właścicieli przedsiębiorstw MŚP wobec zastosowania mobilnego rozwiązania technologicznego ustanowiono główną cechą badaną, abstrahując w tym przypadku od roli innych zmiennych. Ustalenie powodów przystąpienia do rozliczeń mobilnych było celem głównym prezentowanego badania. Z populacji ankiet odrzucono te, w których przedsiębiorcy w ogóle nie korzystali z płatności mobilnych. Analizie końcowej poddano 527 formularzy ankiet. W tabeli 4 wskazano odpowiedzi, których najczęściej udzielali respondenci.

Wyniki uzyskanych odpowiedzi wskazują, że przyczyny są dość zróżnicowane. Wynikają one z oddziaływania zewnętrznego i wewnętrznego, a także z indywidualnych uwarunkowań. Można je określić jako zmienne spowodowane postawami klientów i zgłaszanymi przez nich potrzebami, takimi jak zainteresowanie stosowaniem mobilnych technologii, praktyczność, wygoda, ułatwienia, postawa rezygnacji z zakupów w sytuacjach braku gotówki (czynniki zewnętrzne). Wiele decyzji o wprowadzaniu mobilnych rozliczeń było efektem decyzji samego przedsiębiorstwa, przyjętej przez niego strategii, a także spowodowane było czynnikami wynikającymi z oceny nowych technologii wskazującymi na uzyskiwanie wymiernych korzyści (czynniki wewnętrzne). Największe znaczenie dla małych i średnich firm miało zainteresowanie klientów możliwością zastosowania tej formy płatności. Oznacza to, że otoczenie rynkowe poniekąd wymusza na przedsiębiorcach otwarcie się na tego typu zmiany i jest czynnikiem głównym. W małych firmach był to czynnik decydujący o przystąpieniu do tego typu rozliczeń u $44 \%$ badanych, a w firmach średnich u 55\% ankietowanych. Płatności bez użycia karty występowały głównie w działalności usługowej i handlowej. W transakcjach mobilnych przy wykorzystaniu 
nowoczesnych technologii ważna dla klientów jest oszczędność czasu i użyteczność tego typu transakcji, co jako przyczynek wprowadzonych zmian bardziej akcentowały średnie przedsiębiorstwa. Z kolei przedsiębiorstwa małe wskazywały za istotny powód potrzebę bycie postrzeganymi jako firmy innowacyjne i nowoczesne. Dotyczyło to głównie firm działających w sektorze handlu detalicznego i usług.

Tabela 4. Powody przystąpienia przedsiębiorstw do rozliczeń mobilnych (\% wskazań)

\begin{tabular}{|c|c|c|c|c|c|}
\hline \multirow[b]{2}{*}{ Przyczyny } & \multicolumn{2}{|c|}{ Małe firmy } & \multicolumn{2}{|c|}{ Średnie firmy } & \multirow[b]{2}{*}{ Istotność } \\
\hline & $\begin{array}{c}\text { odpowiedzi } \\
(\%)\end{array}$ & $\begin{array}{c}\text { ranga } \\
\text { czynnika }\end{array}$ & $\begin{array}{c}\text { odpowiedzi } \\
(\%)\end{array}$ & $\begin{array}{c}\text { ranga } \\
\text { czynnika }\end{array}$ & \\
\hline $\begin{array}{l}\text { Zainteresowanie klientów } \\
\text { możliwościami tej płatności }\end{array}$ & 44 & 1 & 55 & 1 & $* * *$ \\
\hline Nowoczesny wizerunek firmy & 18 & 2 & 16 & 3 & $* * *$ \\
\hline $\begin{array}{l}\text { Wygoda, ułatwienie } \\
\text { dla klientów }\end{array}$ & 8 & 4 & 17 & 2 & ** \\
\hline $\begin{array}{l}\text { Powszechność, dostępność } \\
\text { smartfonów }\end{array}$ & 12 & 3 & 13 & 5 & ** \\
\hline $\begin{array}{l}\text { Dywersyfikacja, poszerzenie } \\
\text { oferty }\end{array}$ & 7 & 5 & 10 & 6 & $* *$ \\
\hline $\begin{array}{l}\text { Tańszy i bezpośredni kanał } \\
\text { obsługi klientów }\end{array}$ & 7 & 5 & 15 & 4 & ** \\
\hline $\begin{array}{l}\text { Rezygnacja z zakupów, } \\
\text { przy braku gotówki }\end{array}$ & 17 & 2 & 10 & 6 & * \\
\hline $\begin{array}{l}\text { Zwiększenie } \\
\text { konkurencyjności firmy }\end{array}$ & 8 & 4 & 5 & 8 & * \\
\hline Korzyści z systemu płatności & 6 & 7 & 17 & 2 & * \\
\hline Przyspieszenie rozliczeń & 12 & 3 & 8 & 7 & * \\
\hline
\end{tabular}

Źródło: obliczenia własne

W małych firmach decyzję o przystąpieniu do tego typu nowoczesnych rozliczeń przyspieszały obserwowana w praktyce rezygnacja klientów z zakupów przy braku gotówki, a także zwiększająca się skala stosowania przez klientów smartfonów. W działalności gospodarczej rachunek wyników wdrożeń i uzyskanych korzyści ekonomicznych uznawany jest za główny czynnik sprawczy funkcjonowania i rozwoju firmy. Czynniki ekonomiczne, m.in. tańszy i bezpośredni kanał obsługi klientów, a także wymierne korzyści płynące z zastosowanego systemu płatności były zdecydowanie ważniejsze dla średnich firm, dla których stały się stymulatorem podjętych decyzji i czynnikiem sprawczym zmian. Wzrastająca skala działalności wywiera bowiem większy wpływ na decyzyjność powiązaną z analizą opłacalności przedsięwzięć inwestycyjnych. Korzyści ekonomiczne płynące z zastosowania analizowanych płatności m.in. w postaci tańszego kanału obsługi klientów są ważne dla 6\% małych przedsiębiorstw i aż dla co siódmego przedsiębiorstwa średniej skali. Zauważalne profity z wdrożenia systemu płatności mają podobny rozkład wskazań i różne wartości użytkowe, nie tylko finansowe. Wielu ankietowanych uważa, że ta forma płatności ułatwia im wykonywanie codziennych czynności operacyjnych. Obrót bez użycia karty nie wymaga liczenia i zabezpieczenia gotówki. Szybsza obsługa transakcji oznacza także możliwość obsłużenia większej liczby klientów w tym samym czasie. 
Rozpatrując szerzej wynikły ranking ze względu na istotność wskazań, określono, że kolejnym ważnym motywem przystąpienia badanych do rozliczeń mobilnych w grupie małych i średnich firm okazała się postawa związana z budowaną strategią rozwoju. Strategia nastawiona na budowanie wizerunku firmy jako nowoczesnej i otwartej na nowości technologiczne i innowacje produktowe to wyzwanie współczesnych przedsiębiorstw działających na globalnym rynku. Wyniki ankietowe są zbieżne z wynikami krajowymi. Niemal co piąty przedsiębiorca uwzględnia udostępnienie swoim klientom możliwości płacenia kartą jako część modelu biznesowego firmy, co trzeci decyduje się instalować terminal od samego początku działalności biznesowej (Raport Mastercard, 2019). Co ciekawe, małe firmy województwa podkarpackiego, które wdrożyły mobilne systemy płatności, traktowały te działania optymalizacji modelu biznesowego również jako element zwiększenia swojej pozycji konkurencyjnej. Ranga tych czynników w tej grupie była wysoko notowana w hierarchii uzyskanych ocen. W modelach biznesowych akcentowano na równi potrzebę dywersyfikacji i poszerzenia oferty.

Podsumowując analizy zaistniałych przyczyn wprowadzenia zmian w systemach płatności przedsiębiorstw, odnotowywać należy, że uwarunkowania podjętych decyzji płyną z otoczenia rynkowego, m.in. z postępu technologicznego i zainteresowania klientów dokonywaniem płatności bez użycia karty. Przedsiębiorstwa MŚP stosują płatności mobilne, aby podnieść jakość swoich usług i zwiększyć wzrost wolumenu sprzedaży. Średnie firmy są bardziej zaangażowane w rozpoznawaniu potrzeb rynkowych i wykazują wyższą świadomość dotyczącą wdrażania nowości i postępu do swojej firmy w postaci płatności mobilnych.

Istotnym aspektem poznawczym było również zbadanie czynników determinujących wprowadzenie płatności mobilnych ze względu na lokalizację prowadzonej działalności (tabela 5). Rozpoznanie to prowadzono według wielkości miejscowości, przyjmując za podstawę liczbę ludności miejscowości, w której przedsiębiorca prowadzi i ma zarejestrowaną działalność gospodarczą. Liczba mieszkańców może wyznaczać liczbę potencjalnych klientów firm i zrealizowanych potencjalnych płatności.

Tabela 5. Czynniki determinujące wprowadzenie płatności mobilnych w przedsiębiorstwach MŚP w zależności od miejsca prowadzenia działalności gospodarczej (odpowiedzi w \%)

\begin{tabular}{|l|c|c|c|c|c|c|c|c|}
\hline \multirow{2}{*}{ Wyszczególnienie } & \multicolumn{7}{c|}{ Miejscowość wg liczby mieszkańców } \\
\cline { 2 - 11 } & \multicolumn{2}{|c|}{ do $\mathbf{2 0}$ tys. } & \multicolumn{2}{c|}{$\mathbf{2 0 - 5 0}$ tys. } & \multicolumn{2}{|c|}{$\mathbf{5 0 - 2 0 0}$ tys. } & \multicolumn{2}{c|}{ pow. 200 tys. } \\
\hline Wielkość przedsiębiorstwa & małe & średnie & małe & średnie & małe & średnie & małe & średnie \\
\hline Zainteresowanie klientów & 12 & 16 & 17 & 28 & 27 & 38 & 41 & 52 \\
\hline Strategia nowoczesnej firmy & 7 & 8 & 11 & 12 & 20 & 18 & 16 & 18 \\
\hline Ułatwienie dla klientów & 1 & 8 & 16 & 7 & 15 & 12 & 17 & 15 \\
\hline Powszechność smartfonów & 1 & 5 & 12 & 9 & 16 & 12 & 13 & 15 \\
\hline $\begin{array}{l}\text { Dywersyfikacja poszerzenie } \\
\text { oferty }\end{array}$ & 3 & 4 & 5 & 4 & 7 & 11 & 7 & 12 \\
\hline $\begin{array}{l}\text { Tańszy kanał obsługi } \\
\text { klientów }\end{array}$ & 2 & 2 & 10 & 7 & 10 & 11 & 10 & 18 \\
\hline Rezygnacja z zakupów & 5 & 6 & 17 & 10 & 12 & 14 & 16 & 17 \\
\hline
\end{tabular}

Źródło obliczenia własne 
Lokalizacja działalności determinuje zróżnicowane postawy przedsiębiorców MŚP względem nowoczesnych form płatności. Najbardziej istotne czynniki, czyli zainteresowanie ze strony klientów i obrana strategia, miały największe znaczenie w dużych miastach (powyżej 50 tys. mieszkańców). Dotyczyło to całej populacji badanych bez względu na wielkości firmy. Średnie firmy w większych miejscowościach wskazywały, że czynnikami wpływającymi na zmianę i zastosowanie nowoczesnych systemów rozliczeń były: przebranżowienie, poszerzenie zakresu działalności gospodarczej i zmiana profilu dotychczasowej aktywności. Druga grupa powodów o średniej istotności wpływu na decyzje przedsiębiorstw związana z zgłaszanym przez klientów udogodnieniem, wygodą i praktycznością czy faktem zjawiska szerszego posiadania smartfonów była zauważana bardziej przez małe firmy już w miejscowościach z liczbą mieszkańców 20-50 tys. i większych. Małe firmy zatem bardziej reagują na potrzeby otoczenia zewnętrznego i szybciej dostosowują się do wymagań klientów. Uwzględniany w decyzjach przedsiębiorców czynnik ekonomiczny w postaci tańszego i kanału obsługi klientów wynikający z jego bezpośredniego charakteru miał znaczenie tylko w średnich firmach i to funkcjonujących w dużych miastach, głównie wojewódzkich. Ciekawym, lecz ambiwalentnym czynnikiem z grupy powodów zauważanych, ale mniej istotnych w ujęciu całej badanej populacji, była stwierdzona rezygnacja klientów z zakupów u badanych, przy braku bieżącej gotówki. Czynnik ten był powodem akceptacji urządzeń do płatności mobilnych przez przedsiębiorców w miejscowościach z liczbą mieszkańców 20-50 tys. i powyżej 200 tys. Podkreślić należy, iż w mniejszych miejscowościach to właśnie ten czynnik był znaczący w decyzjach przedsiębiorców głównie małych o wyborze mobilnej formy płatności. Dalej wraz ze wzrostem wielkości miejscowości stabilizował swoje wskazania, zarówno dla małych, jak i średnich przedsiębiorstw. Duży odsetek przedsiębiorców, głównie w mniejszych miejscowościach, nie wskazuje żadnych czynników lub zakres wskazań jest bardzo niski, co świadczyć może o braku zajęcia stanowiska względem płatności mobilnych, a także o braku pogłębionych analiz nad poszerzającym się zjawiskiem płatności bez użycia karty. Elementy wielkości przedsiębiorstwa i wzrostu skali mogą być czynnikiem dalszych zmian w obszarze zwiększania przyjmowania płatności bez użycia karty. Powody wynikające z mniejszych kosztów zakupów kasy i dzierżawy terminali mogą być zachętą do inwestowania w analizowany rodzaj produktów finansowych w najmniejszych miejscowościach. Znormalizowany standard miałby duże znaczenie, ale regulacje ustawowe dla płatności bezkartowych nie są rozważane jako obowiązkowe. Zatem liczba mieszkańców i klientów może oddziaływać na przyszłe zmiany postaw przedsiębiorców i determinować ich wybory dla wdrożenia płatności zbliżeniowych.

\section{Zakończenie}

Na podstawie zaistniałych zasobów i obserwacji tendencji rynkowych zbadano problem otwarcia się na płatności mobilne w małych i średnich przedsiębiorstwach. Stwierdzono, że istnieją dwa główne powody wprowadzania mobilnych systemów płatności. Jednym z nich jest determinanta rynkowa związana ze zwiększającym się poziomem zainteresowania klientów zastosowaniem tej formy płatności w realizowanych transakcjach bezpośrednich. Drugim ważnym czynnikiem jest gotowość badanej grupy przedsiębiorstw do zmiany strategii firmy w kierunku bycia nowoczesną i innowacyjną. Zmiany te wynikają $\mathrm{z}$ otoczenia rynkowego, w którym funkcjonują przedsiębiorstwa, a potrzeba wdrażania 
zmian na rzecz płatności mobilnych jest zauważana przez przedsiębiorstwa. Te dwa motywy są ważne zarówno dla małych, jak i dla średnich przedsiębiorstw, i wzajemnie się uzupełniają. Jak potwierdziły wyniki przeprowadzonych badań, zainteresowanie płatnościami mobilnymi w większym zakresie stwierdza się w średnich przedsiębiorstwach. Firmy te są bardziej zaangażowane w rozpoznawanie potrzeb rynkowych i wykazują wyższą gotowość do wdrażania nowości związanych z płatnościami mobilnymi. Barierą nie są koszty wdrożenia i utrzymania oprzyrządowania. Większe znaczenie mają przekonanie się do funkcjonalności płatności oraz empiryczna weryfikacja, że zastosowanie tych form płatności wpływa na zwiększenie skali obrotów ze sprzedaży. Dla małych firm ważnym elementem stymulującym wdrożenie tych płatności okazały się bezpośrednie oddziaływanie i obserwacja związana z rezygnacją z zakupów przez klientów. Lokalizacja działalności w większych miastach determinuje aktywne postawy przedsiębiorców względem nowoczesnych form płatności. Bardziej otwarte na zmiany są średnie przedsiębiorstwa w dużych miastach. W dużych miejscowościach ważnym czynnikiem do wprowadzenia płatności mobilnych może być wzrost skali prowadzonej działalności i zmiana profilu istniejącej działalności. Małe i średnie przedsiębiorstwa mają potencjał rozwoju dla nowoczesnych mobilnych form płatności, a analizy jego wykorzystania i badanie gotowości do zmian wydają się być ciekawym nurtem dalszych badań i analiz. Potencjał przedsiębiorstw tkwi w zasobach infrastrukturalnych i wzrastającej świadomości nadchodzących zmian.

Literatura

References

Borcuch, A. (2007). Pieniądz elektroniczny - pieniądz przyszłości. Analiza ekonomiczno-prawna. Warszawa: CeDeWu.

Chmielarz, W. (2004). Analiza porównawcza systemów płatności w handlu elektronicznym. W: J. Kisielnicki (red.), Informatyka narzędziem wspótczesnego zarządzania. Warszawa: Wydawnictwo Naukowe PJWSTK.

Chmielarz, W. (2005). Systemy elektronicznej bankowości. Warszawa: Difin.

Czarny, B. (2018). Podstawy ekonomii. Warszawa: PWE.

Davis, F. (1989). Perceived usefulness, perceived ease of use and user acceptance of information technology. MIS Quarterly, 13, 45-50.

Eftekhari, N., Bogers, M. (2015). Open for entrepreneurship: How open innovation can foster new venture creation. Creativity and Innovation Management, 24(4), 574-584.

Filip, P. (2017). Development of individual entrepreneurship in Poland under crisis conditions. Ovidius University Annals. Economic Sciences Series, XVII(1), 484-479.

Ghobakhloo, M., Arias-Aranda, D., Benitez-Amado, J. (2011). Adoption of e-commerce applications in SMEs. Industrial Management and Data Systems, 111(8), 1238-1269. doi: 10.1108/0263557 1111170785

GUS. (2019). Społeczeństwo informacyjne w Polsce. Wyniki badań statystycznych $z$ lat 2012-2018. Warszawa: GUS.

Hossain, M. (2015). A review of literature on open innovation in small and medium-sized enterprises. Journal of Global Entrepreneurship Research, 5(1), 6.

IPSOS dla Fundacji Rozwoju Obrotu Bezgotówkowego. (2017). Postawy i zachowania przedsiębiorców $z$ sektora MŚP wobec obrotu bezgotówkowego. Raport z badania. Warszawa: IPSOS dla Fundacji Rozwoju Obrotu Bezgotówkowego. 
Kim, Y., Choi, J., Park, Y.J., Yeon, J. (2016).The adoption of mobile payment services for finch. International Journal of Applied Engineering Research, 11(2), 1058-1061.

Kozakiewicz, M., Kwas, M. (2014). Prognoza wybranych wskaźników rozwoju obrotu bezgotówkowego na lata 2014-2020. Warszawa: Szkoła Główna Handlowa, NBP.

Maciejewski, K., Polasik, M. (2019). Innowacyjne usługi płatnicze w Polsce i na świecie. Materiały i Studia NBP, 241, 19-22.

NET@bank, Związek Banków Polskich (2019, 10 września). Raporty: Bankowość internetowa i płatności bezgotówkowe. Pozyskano z: https://www.zbp.pl/raporty-i-publikacje/raporty-cykliczne/ raport-netbank

NBP. (2019, 10 września). Informacja o kartach płatniczych. Dane z lat 2015-2018. Pozyskano z: https:// www.nbp.pl/

Pacak, M. (2014). Usługi płatnicze. Komentarz. Warszawa: LexisNexis.

Pearson, J.M., Grandon, E. (2006). An empirical study of factors that influence E-commerce adoption/ non-adoption in small and medium sized businesses. Journal of Internet Commerce, 4(4), 1-21. doi: 10.1300/J179v04n04_01

Raport Mastercard (2019). Przedsiębiorca w bezgotówkowym świecie. Pozyskano z: https://newsroom. mastercard.com

Szmigielska, B., Wolski, K., Jaszczak, A. (2012). Modele wyjaśniające zachowania użytkowników internetu. E-mentor, 3(45).

Ustawa z dnia 12 września 2002 r. o elektronicznych instrumentach płatniczych. Dz.U. nr 169 z 2012 r., poz. 1232 ze.zm.

Ustawa z dnia 19 sierpnia 2011 r. o ustugach płatniczych. Dz.U. z 2019 r., poz. 659, 730 i 1495.

Ustawa $z$ dnia 10 maja 2018 r. o zmianie ustawy o usługach płatniczych oraz niektórych innych ustaw. Dz.U. z 2018 r., poz. 1075.

Ustawa z dnia 6 marca 2018 r. Prawo przedsiębiorców. Dz.U. z 2018 r., poz. 646.

Paulina Filip, dr. Jest adiunktem w Katedrze Finansów i Rachunkowości w Instytucie Ekonomii i Finansów na Uniwersytecie Rzeszowskim. Od lat zajmuje się badaniem zmian w polskich przedsiębiorstwach małej i średniej skali w ujęciu lokalnym i globalnym. Swoje badania koncentruje na nowoczesnych formach finansowania polskich przedsiębiorstw, zmianach w alokacji dostępnych zasobów, zwłaszcza kapitału finansowego, oraz badaniu opłacalności prowadzonej działalności w kierunku poprawy efektywności gospodarowania.

Paulina Filip, $\mathrm{PhD}$. She is an assistant professor in the Department of Finance and Accounting in the Institute of Economics and Finance at the University of Rzeszów. For years, she has been studying changes in Polish small and medium-sized enterprises at the local and global level. Her research focuses on modern forms of financing Polish enterprises, changes in the allocation of available resources, especially financial capital, as well as research on the profitability of conducted activities to improve business efficiency.

ORCID: https://orcid.org/0000-0003-1786-318X

\section{Adres/Address:}

Uniwersytet Rzeszowski

Kolegium Nauk Społecznych

Instytut Ekonomii i Finansów

Katedra Finansów i Rachunkowości

ul. M. Ćwiklińskiej 2a

35-959 Rzeszów, Polska

e-mail: paola@ur.edu.pl 